\title{
ARTÍCULOS
}

\section{CURRENT AND FUTURE TRENDS IN INFORMATION TECHNOLOGIES FOR INFORMATION UNITS}

\section{Marshall Breeding}

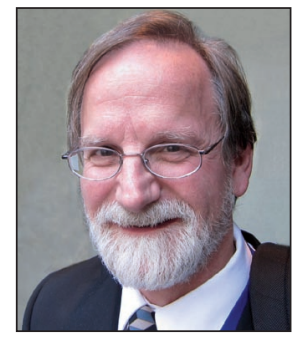

Marshal Breeding is director for Innovative Technology and Research at Vanderbilt University Library and the Executive Director of the Vanderbilt Television News Archive. He is founder and publisher of Library Technology Guides. He earned a Bachelor of Arts in Philosophy (1980) and a Masters of Arts (1982) from Colorado State University and a Masters of Arts from Vanderbilt University (1985). He serves as editor for Smart Libraries Newsletter published by ALA TechSource, writes Systems Librarian column for Computers in Libraries published by Information Today, and has authored the Automation Marketplace feature for Library Journal since 2002.

Vanderbilt University Library 110 Twenty-first Avenue South, Suite 704 Nashville, TN 37203, USA http://www.librarytechnology.org marshall.breeding@librarytechnology.org

\begin{abstract}
With the increasing dominance of electronic content and digital collections in academic libraries, the capabilities lacking in the current slate of automation systems has increasingly become an obstacle to progress. A new generation of digital services platforms for libraries is emerging, designed to provide a more comprehensive approach to the management and access to all formats of library materials: print, electronic and digital. These new systems involve a modernization of technology, embracing service-oriented architectures, availability for APIs to facilitate interoperability with external systems, support for task workflows more aligned with current operational realities, and more tightly coupled discovery interfaces that deliver access to library collections and services in a more unified and comprehensive manner. These new products, emerging in this era of cloud computing, have been designed for deployment through software as a service and rely on highly shared data models.
\end{abstract}

\section{Keywords}

Libraries, Library management systems, Integrated library systems, Web based services, Infrastructure, Digital collections, Digitization, Library collections, Discovery software, eBooks, eJournals, Software as a service, Cloud computing.

\section{Título: Tendencias actuales y futuras en tecnologías de la información para unidades de información}

\section{Resumen}

Con la fuerte irrupción de las bibliotecas en el acceso a los recursos electrónicos y la gestión de colecciones digitales, la oferta actual de sistemas de automatización se ha ido convirtiendo en un obstáculo para el progreso. Una nueva generación de plataformas de servicios digitales para bibliotecas está emergiendo, diseñada para proporcionar un apoyo integral para la gestión y el acceso de todos los formatos de materiales de la biblioteca: impresos, electrónicos y digitales. Estos nuevos sistemas implican una modernización de las arquitecturas orientadas a servicios, con un mayor desarrollo del concepto de "software como servicio" y de otros modelos basados en la "nube".

\section{Palabras clave}

Bibliotecas, Sistemas de gestión de bibliotecas, Sistemas integrados de bibliotecas, Servicios basados en la web, Infraestructura, Colecciones digitales, Digitalización, Software de discubrimiento, Libros electrónicos, Revistas electrónicas, Software como servicio, Computación en la nube.

Breeding, Marshall. "Current and future trends in information technologies for information units". El profesional de la información, 2011, v. 21, n. 1, pp. 9-15. 


\section{Introduction}

This paper is based on a presentation made at the IX Conferencia Internacional sobre Bibliotecas Universitarias, organized by Dirección General de Bibliotecas of the Universidad Nacional Autónoma de México (UNAM), México DF, October 26th-28th 2011.

In 1996 the UNAM's General Directorate of Libraries celebrated its thirtieth anniversary with a series of lectures and panel discussions in which the central idea was to imagine the features of the library of the future at that time. In this paper we intend to analyze how the library of the future is being built and how it would be in 15 years from now, in 2026.

Academic libraries today find themselves at a critical juncture between the automation systems of the past and a new genre of emerging technologies. This essay aims to look forward to anticipate the progression of technologies and automation systems. Five-year projections can extend the current trends to estimate the progress by 2016 of developments and trends in place today. Following the charge of the panel discussion on which this essay is based, these trajectories are extended another decade to the year 2026, but must be considered more speculative.

How libraries develop and implement their technology strategies will be informed by opportunities or limitations defined by the larger scholarly publishing landscape, paradigm shifts in technology architectures, and the legal and business environment related to intellectual property and copyright

A variety of factors will shape the state of libraries of the future, both at the 5 and 15 year horizons. How libraries develop and implement their technology strategies will be informed by opportunities or limitations defined by the larger scholarly publishing landscape, paradigm shifts in technology architectures, and the legal and business environment related to intellectual property and copyright. Progress for libraries will also relate to their economic situation and their access to related resources, including network and computing infrastructure, Internet bandwidth, and the level of interest and ability for their users to take advantage of computer and web-based services and many other factors. Painting trends with a broad brush may not account for the finer details that reflect the realities of libraries in different international regions or specialized environments.

The Technological Resources Panel was asked to analyze the prospective of technological infrastructure and its implementation in library services and activities, imagining technical infrastructure in academic libraries in 2026, including:

- Projections made on trends underway today.

- Disruptions can produce radically different long-term outcomes.
- Present an optimistic view that libraries will maintain key role in academic institutions.

- Acquire, manage, and deliver access to information in support of teaching and research.

\section{Assumptions regarding library collections}

\subsection{1: Transition toward electronic and digital content}

Today, organizations involved in the creation of software for libraries have entered a new phase of competition. Following a period of research and development that aimed to provide alternatives to libraries, both in back-end automation and end user discovery, a slate of new solutions have emerged, often representing quite different conceptual models. In a continued trend, librarians seek solutions that immediately improve the experiences of their users, especially via discovery products.

These new automation products arise in the context of the realities that shape the work of academic libraries, especially related to the ever increasing proportions of electronic and digital materials that comprise library collections. The transition from print to electronic formats has largely run to completion with scholarly journals. The vast majority of journal articles are now available in electronic form, with many libraries shifting away entirely from printed subscriptions, even when available. An increasing number of scholarly journals follow an open access model where articles are freely available, mostly due to up-front fees paid by the authors. Monographs also see great changes in format options. E-books have been available for many years, though usually to supplement print copies, and embedded within aggregated databases of specialized materials. Today we are approaching a tipping point where interest in e-books has risen dramatically in public libraries in tandem with the proliferation of a large array of e-reading devices. E-book lending now ranks as one of the top concerns for public libraries; academic libraries will not be far behind and also need significantly better tools for managing this growing component of their collections. Today most academic libraries routinely create and provide access to collection of digital objects, including documents, photographs and other images, video content, and sound recordings.

\subsection{6: All new content produced electronically}

By 2016 we should expect significant movement toward the digital realm on many fronts. Electronic scholarly articles, possibly disaggregated from specific e-journals will reach near 100 percent penetration, with ever higher amounts of open access materials. Though the proportions of open access content will have continued to increase, traditional subscriptions will remain dominant by this date. E-books may achieve majority status in academic libraries, and any new monographic acquired in print form will be exceptionally rare. Academic and research libraries with large legacy collections of print monographs will continue to maintain those collections, though the majority of these collections will be relegated to remote storage facilities, available upon request. I also anticipate that most library procurements will be based on patron-driven acquisitions. The combina- 
tion of limited resources and the options to acquire digital editions with near immediate delivery alleviates the need for librarians purchase large amounts of resources that may never see use. By this time, libraries will also supplement their legacy print collections with global resources of digital books from the HathiTrust, Google Books, the Open Library, and other initiatives specific to geographic regions and languages. Access to digital resources will increasingly be globalized through initiatives such as Europeana and the Digital Public Library of America. By this time all new content will be routinely produced electronically.

\subsection{6: No technical obstacles but likely legal con- straints}

Looking further forward to 2026 we can anticipate these trends to be even more fully realized. Academic libraries will operate in a thoroughly digital arena. All new content will be acquired, increasingly collaboratively, in some kind of digital form. The technical capability will long since have been achieved to create digital representations of all books, articles, manuscripts, archives, maps, and other materials of interest to academic libraries. With the intervening decade since new content shifted to digital creation, current research materials can naturally be expected to be readily available for incorporation into a library's digital collections. Libraries will expect discovery services that truly represent the entire body of scholarly content available to their users across a wide range of media and formats, including materials available through resource sharing arrangements.

While the technical obstacles for digital dominance by 2026 will be entirely obliterated, events on the business and legal front will stand as the most likely constraining factors. It's not guaranteed that the processes to digitize the remaining analog books not in the public domain will continue an ever more severe intellectual property environment. The outcome of legal battles taking place today among libraries, publishers, author's groups and other content stakeholders stand to make an enormous impact on the long-term digital future of libraries. In recent days, for example, the United States has seen proposed legislation that would undo major accomplishments in open access, such as the mandatory posting of articles derived from research funded by the United States federal government. Constant vigilance and advocacy will be essential to ensure that libraries maintain a strong position in the digitally dominant future. But barring legal obstacles, technologies will be available in 2026 to deliver powerful access to the entire body of scholarly content.

\section{Impact on library management systems}

Advancing from the present to the future, libraries will also undergo major transformations regarding their needs for management systems. We can anticipate a transition from the integrated library systems (ILS) in place today to a new genre of library services platforms, embracing major changes in the management, access, and fulfillment of library resources consistent with the transformations described above and with other changes underway in the realm of scholarly publishing and scientific research.
It's safe to say that in 2011 integrated library systems dominate the scene. This model of library automation, based on modules of cataloging, circulation, acquisitions, serials management, and online catalog was established as early in the 1970's when libraries dealt primarily with print materials and has evolved too little since. The ILS tends to operate in a self-contained way, communicating with external systems primarily though library-specific protocols such as Z 39.50, SIP or NCIP, ISO ILL and based on library specific data formatting conventions such as MARC21 or Unimarc.

The traditional ILS model does not lend itself to the management of electronic resources and has led to the proliferation of supplemental products to address this increasingly strategic aspect of library operations. Today, academic libraries, in addition to their ILS, routinely implement OpenURL-based link resolution services, specialized electronic resource management systems, discovery interfaces, digital asset management platforms, institutional repositories, proxy servers, and other components addressing one aspect or another of a library's digital operations.

In addition to their ILS, academic libraries routinely implement many other software components, resulting in a very complex environment for the library to manage

Each of these applications tends to require separate implementation and management processes and hardware platform, resulting in a very complex environment for the library to manage, exceeding the resource capacity of many libraries. These systems often fail to interoperate with each other effectively, due to isolated data models and a lack of robust APIs.

\subsection{Library services platforms}

2011 marks the beginning of a new cycle of library automation that will take hold by 2016, with full maturity by 2026. Following two or three years of research and development, a new slate of products launched in 2011-12, that I term library services platforms, aim to take a much more comprehensive approach to managing content resources.

While each brings its own distinctive features and design characteristics to the table, these library services platforms generally aim to manage all types of resources, offering specialized workflows depending on whether the item is analog or digital, local or remote, purchased or licensed. They mostly incorporate highly shared data models, following a metadata lifecycle approach that favors processing of batches or streams of metadata from external feeds, enriching records as possible through automated and manual processes. These platforms also take a more agnostic approach relative to metadata formats, supporting major library and non-library standards, including MARC21, Unimarc, Dublin Core, METS, MODS, MARC/XML, ONIX, and others. The availability of a robust suite of application programming interfaces, or APIs, will stand as one of the key defining characteristics 
of this new genre of library services platforms. The "platform" aspect of this genre provides the ability for library programmers to access the data and functionality of these systems to create new services beyond those delivered, to construct new interfaces and widgets, and to dynamically connect with external systems within the library's own enterprise network, that of its parent institution, or with external partners or providers.

\section{The new library services platforms will} provide the ability for library programmers to access the data and functionality to create new services beyond those delivered

This brief summary gives only a glimpse of this new model of library automation that takes a radically divergent approach to the ILS model. Figure 1 presents something of a visual representation of a general schematic of the orientation of these new products.

2011 and 2012 saw, or will see the launch of several of these new platforms, including: OCLC's WorldShare Management Services, Alma from Ex Libris, Serials Solutions Intota, Sierra from Innovative Interfaces, and the open source Kuali OLE project. But these are the systems of the future more than the present with vast majority of academic libraries today operating traditional ILS products such as Millennium, Voyager, Aleph 500, SirsiDynix Symphony, Horizon, VTLS Virtua, Vubis Smart, and others that vary by global region.

\subsection{Full maturity of LSP by 2026}

By 2016, we can expect to see implementation of the new library service platforms in significant proportions. But a timeframe of only five years from now is not necessarily sufficient to complete generational changes. Given that even today, previous ILS more than a decade past the point when they have been actively developed, such as Geac Advance or Dynix Classic, remain in use in at least some libraries, reflecting the reality that some libraries take a very long time to acquire and implement new products. Libraries with limited resources often have little choice but to make the best of outdated automation systems. Historically, the full completion of a cycle from existing legacy products to new flagship offerings spans over a decade.

Turning the calendar forward to 2026, we can speculate the realm of library services platforms to reach full maturity and near universal deployment. In the same way that almost any academic library today has implemented an integrated library system of some sort, by 2026 we can expect routine use of platforms capable of comprehensive resource management across print, electronic, and digital formats. Many of the automation products used in academic libraries back in 2011 will be extinct, especially those offered by organizations offering new platforms.

I also expect that at least some of the products in use today to survive though 2026, though the intervening years of evolution will render them almost unrecognizable relative to their current form, and they will have taken on many of the traits of the library services platforms launched in 2012. The library automation environment has always been favorable to an evolutionary approach to product development, even though the cycle underway today introduces a number of revolutionary alternatives. Several vendors have been able to successfully navigate through a long series of technology cycles, including Innovative Interfaces, Inc., VTLS, SirsiDynix (and its predecessor companies), and Ex Libris, and we can anticipate that these, and others, will continue to evolve existing products or create new ones through the next era of library automation.

\section{Library automation technologies have historically seen cycles of about 10 years}

The emerging technologies of today will inevitably turn into the legacy systems of the future. Given that library automation technologies have historically seen cycles of about 10 years, we should anticipate that beginning in about 2020 sufficient change will have transpired in academic libraries, technologies, and scholarly publishing to spark the next wave of innovation and product development. 2026 may well be a time when the systems we see today as the wave of the future may be due for redevelopment or replacement. The technology and business cycles of library automation churn relentlessly.

\section{Cloud computing}

In 2011 cloud computing has entered the mainstream. Though the majority of libraries today operate local servers, an increasing number are shifting to vendor hosting ar-

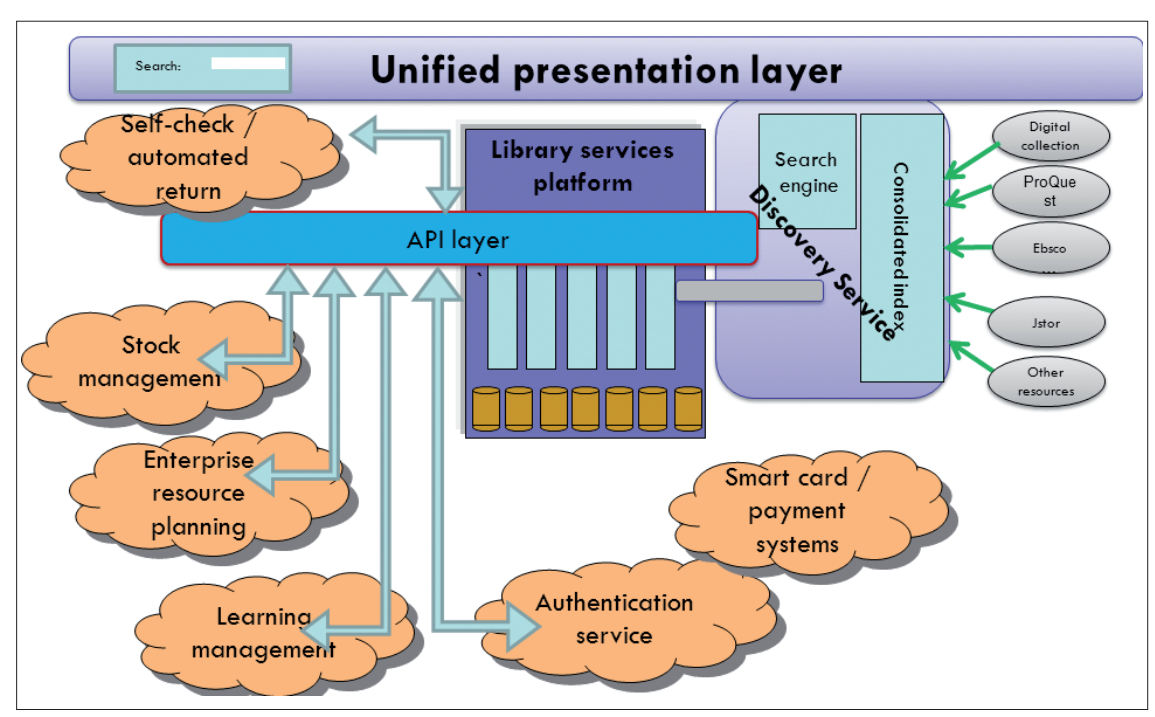

Figure 1. General schema of the library services platforms 
rangements or software as a service (saas). Today's legacy systems are moving rapidly to vendor-hosted arrangements. New products are generally being design for multi-tenant software as a service deployment. Today we can see that the wheels are in motion for a steady advance toward cloud computing. Internationally, libraries in some regions do not find cloud computing as a viable option due to the lack of adequate internet bandwidth.

We can expect cloud computing to play a much more dominant role by 2016 . The new slate of library services platforms will natively embrace cloud computing. But even those libraries continuing with traditional integrated library systems will shift from local installations to software as a service. By 2016, locally managed servers for library automation systems will be a minority approach. Internet bandwidth should be sufficient in almost all international regions to support cloud computing.

By 2026 , should the trajectory of the current trends remain reasonably on course, we might anticipate that almost all computer services will be deployed through cloud computing models, including the core automation and discovery services implemented by academic libraries. By this date the needed infrastructure of robust internet bandwidth should be present ubiquitously, including both high-speed connections to data centers and wireless communications to individual users. Mobile devices will far outnumber desktop and laptop computers.

\section{The automation systems themselves likewise will be offered as open source software routinely by 2026}

\section{Open source software}

We can expect that open source software see steady growth over the next fifteen years. Today we see a vigorous competition between library automation systems offered through proprietary licenses and those available as open source software. Over time, library automation products will include increasing proportions of open source components. The automation systems themselves likewise will be offered as open source software routinely by 2026.

If the trend toward cloud computing that we noted above comes to pass, the license models of the automation products becomes at least somewhat less relevant. In the multitenant software as a service model, the concept of individual libraries modifying the source code does not really apply. The dynamics of a cloud-based automation environment blur many of the distinctions seen with locally deployed software. In general, both open source and proprietary systems will involve a business model based on subscriptions to services.

Given the general orientation of libraries to prefer open systems, over the course of the next 15 years I anticipate a shift accordingly towards open source licenses, even by the organizations that today offer proprietary software. In the future, points of differentiation for all products -includ- ing both open source and proprietary- will focus on characteristics such as quality of support, the functionality of the system, the relative power of the APIs offered, as well as competitive pricing of the subscription and service fees.

\section{If the trend toward cloud computing comes to pass, the license models of the automation products becomes less rel- evant}

\section{Discovery services}

Beginning in about 2005, one of the key trends in library automation involved the emergence of discovery interfaces that offered an improved way of accessing library collections than the online catalog modules that were delivered as part of their ILS. These discovery interfaces offered a more modern search experience, including features such as relevancy-ranked results, faceted browsing, and more intuitive and attractive page designs. Beginning about 2010 a set of discovery services, oriented primarily oriented to academic libraries, came out with an expansive vision of search that included access to the articles and other information available through a library's subscriptions to electronic resources. This slate of discovery services included Summon from Serials Solutions, Primo Central from Ex Libris, and Ebsco Discovery Service. In 2012 an increasing number of academic libraries will be shifting away from the online catalog module that was delivered with their ILS to a more broadbased discovery service.

Discovery products will dominate by 2016. Traditional library catalogs will serve mostly as specialized tools for researchers needing to work closely with the library's physical materials and manuscript collections. We can anticipate that the discovery services available by this time will offer much more sophisticated access to library services and collections than those in place today. The generalized keyword-oriented search technologies will have been extended to include more effective means of ranking and selecting results. We might anticipate better use of social and associative metadata to improve search results. A decade after the start of the technology cycle of discovery products, we can expect that this genre to reach a state of full maturity and near universal deployment among academic libraries.

\section{By 2016 we can expect discovery prod- ucts to reach a state of full maturity and near universal deployment among aca- demic libraries}

Discovery services will have advanced significantly by 2026 . It seems reasonable to believe that most of the shortcomings of content discovery will be resolved. Collections will be fully represented in the indexes of the discovery services and at a highly granular level. Indexes will routinely incorporate the full text of books, articles, newspapers and other 
textual material; audio will be represented through both transcriptions and speech-based searching. High-quality metadata will enhance search capabilities. We can reasonably expect that library discovery services will provide access to the body of library materials, spanning all disciplines and media types, with at least the breadth and sophistication that search engines such as Google offer for searching the Web.

\section{Metadata and progress toward the semantic web}

In 2011, the semantic web and the realm of open linked data made no significant impact on library automation products or discovery services. New initiatives such as RDA (resource description and access) were launched to bring at least some of the characteristics of linked data to the ways that libraries describe their materials. Other efforts with even more potential to propel libraries toward more interoperable metadata practices include the announcement that the Library of Congress will begin investigating alternatives to MARC as the carrier for its bibliographic records.

By 2016 we might expect that RDA will overtake AACR2 as new bibliographic metadata is created, but that it will make only incremental improvements in the ways that automation systems or discovery services make more meaningful use of metadata. Yet, interest in bringing semantic web principles may spark other initiatives in how metadata can be structured.

One might optimistically hope that by 2026 the semantic web will constitute a major part of the metadata fabric that underlies library services platforms and discovery services. Any success in operationalizing open linked data should result in advances in how libraries and library users gain access to metadata and content in ways that reduce the dependence on commercial environments that currently restrict their availability.

\section{By 2026 there will be a fewer number} of organizations producing library automation products, each with very broad global reach and extensive product development and support capacity

\section{General forecast}

The cycles of technology take a toll on industry players and products. Some companies may lag behind in innovation and research and development needed to move forward successfully. Each phase of the ongoing cycles of technology tends to narrow the field of competitors. Companies not able to successfully develop and market products consistent with current technology architectures and library expectations become vulnerable to the inevitable industry consolidation produced though business cycles of mergers and acquisitions. 2026 might bring a business environment of a much fewer number of organizations producing library automation products, each with very broad global reach and extensive product development and support capacity. Globalization will have a major impact on the library automation industry, though I expect that some national and regional companies to continue to prosper and to offer significant competition.

While the library automation products available will achieve maturity and technical sophistication relative to most library demands and requirements apparent today, we can also anticipate that new challenges will arise that will in turn require ever new dimensions of technology support.

While it's tempting to imagine a world by 2026 that solves all of the problems that impede libraries today, it would be naïve to hold an overly optimistic view. Throughout the history of library automation, the demands of libraries have consistently outpaced the development of technology products that deliver appropriate support. Even though technology advances rapidly, the forces that challenge and complicate the future of libraries seem to move even faster. Surely other issues will emerge that will disrupt some of the current trends and will demand technology and automation systems to turn in other directions other than the ones addressed in this essay.

This exercise in which we speculate on the state of libraries and library technologies by 2026 must be taken with a healthy dose of skepticism. While it's interesting to think about the trajectories currently in motion, we must recognize that no crystal ball can give a true look that far into the future and that any variety of unanticipated factors and events could propel libraries of the future into quite different directions.

\section{Bibliography}

Arriola-Navarrete, Óscar; Tecuatl-Quechol, Graciela; González-Herrera, Guadalupe. "Software propietario vs software libre: una evaluación de sistemas integrales para la automatización de bibliotecas". Investigación bibliotecológica, 2011, v. 25, n. 54. pp. 37-70.

http://www.ojs.unam. $m x /$ index.php/ibi/article/view/27480

Breeding, Marshall; Yelton, Andromeda. Librarians' assessments of automation systems: Survey results, 2007-2010, Library technology reports, American Library Association, 2011, May-June, v. 47, n. 4, pp. 5-8. ISSN 0024-2586 (Print). http://www.alatechsource.org/taxonomy/term/106/ librarians-assessments-of-automation-systems-surveyresults-2007-2010

Breeding, Marshall. "A cloudy forecast for libraries". Computers in libraries, 2011, v. 31, n. 7, pp. 32-34.

Breeding, Marshall. "Transformations in academic libraries demand transformed automation support". Computers in libraries, 2011, v. 31, n. 4, pp. 27-29.

Cho, Jane. "Study on a saas-based library management system for the Korean library network". The electronic library, 2011, v. 29, n. 3, pp. 379-393.

http://dx.doi.org/10.1108/02640471111141115

Fronk, Elizabeth. "A review of 'next-gen library catalogs'". Journal of web librarianship, 2011, v. 5, n. 1, pp. 74-75.

http://dx.doi.org/10.1080/19322909.2011.544564 
Gerolimos, Michalis; Konsta, Rania. Services for academic libraries in the new era. D-lib magazine, 2011, v. 17, n. 7-8. http://www.dlib.org/dlib/july11/gerolimos/07gerolimos. html

http://dx.doi.org/10.1045/july2011-gerolimos

Gross, Julia; Sheridan, Lutie. "Web scale discovery: the user experience". New library world, 2011, v. 112, n. 5/6, pp. 236247.

http://dx.doi.org/10.1108/03074801111136275

Hane, Paula; Hawkins, Don. "CIL: Focus and value for library communities". Information today, 2011, May, v. 28, n. 5, pp. 20-21.

Jackson, Darla W. "Thinking about technology...: Watson, answer me this: will you make librarians obsolete or can I use free and open source software and cloud computing to ensure a bright future?". Law library journal, 2011, n. 103, p. 497.

Liu, Jia. "Digital library and digital reference service. Integration and mutual complementarity". Educational futures rethinking theory and practice. In: R. Rikowski (ed.) Digitisation perspectives, 2011, v. 46, part VI, pp. 191-212. http://dx.doi.org/10.1007/978-94-6091-299-3_12

Nesta, Frederick; Mi, Jia. "Library 2.0 or library III: returning to leadership". Library management, 2011, v. 32, n. 1/2, pp. 85-97.

http://dx.doi.org/10.1108/01435121111102601

Yang, Sharon Q.; Hofmann, Melissa A. "Next generation or current generation?: A study of the opacs of 260 academic libraries in the USA and Canada". Library Hi Tech, 2011, v. 29, n. 2, pp. 266-300.

Wynnea, Susan C.; Hanscoma, Martha J. "The effect of next- generation catalogs on catalogers and cataloging functions in academic libraries". Cataloging \& classification quarterly, 2011, v. 49, n. 3, pp. 179-207.

http://dx.doi.org/10.1080/01639374.2011.559899

Žumer, Maja. "Next-gen library catalogs". Program: electronic library and information systems, 2011, v. 45, n. 1, pp. 122-123.

\section{Other recent bibliography by Mr. Marshall Breeding \\ (recommended by the editor for further reading)}

Breeding, Marshall. "A smart approach to RFID technologies". Smart libraries newsletter. American Library Association, 2010, November, v. XXX, n. 11.

http://alatechsource.metapress.com/content/I72006156 702

Breeding, Marshall. "The state of the art in library discovery 2010". Computers in libraries, 2010, Jan.-Feb., v. 30, n. 1, pp. 31-34.

Breeding, Marshall. "Leveraging technology for success in a challenging economy". Computers in libraries, 2010, April, v. 30, n. 3, pp. 24-26.

Breeding, Marshall. "Using technology to enhance a library as place". Computers in libraries, 2011, v. 31, n. 3, pp. 2931.

Breeding, Marshall. "Discovering Harry Pottery barn". Computers in libraries, 2011, v. 31, n. 2, pp. 21-23.

Breeding, Marshall. "Preparing for the long-term digital future of libraries". Computers in libraries, 2011, v. 31, n. 1, pp. 24-26.

\section{Próximos temas centrales}

Marzo 2012

Mayo 2012

Julio 2012

Septiembre 2012

Noviembre 2012

Enero 2013

Marzo 2013

Mayo 2013
Publicación científica y acceso abierto

Organización del conocimiento

Comunicación digital

Información y derecho

Bibliotecas académicas

Soportes digitales

Educación y biblioteca

Bibliotecas y documentación de museos

Los interesados pueden remitir notas, artículos, propuestas, publicidad, comentarios, etc., sobre estos temas a: http://recyt.fecyt.es/index.php/EPI/index 